\title{
The effect of intravitreal injection into different quadrants on pain score
}

\section{İntravitreal enjeksiyonun farklı kadranlara yapılmasının ağrı skoruna etkisi}

\author{
Özlem Güller ${ }^{1}$, Selma Urfallığlı², Mete Güiler ${ }^{2}$
}

Kahramanmaraș Sütçü İmam University, School of Medicine, Department of Emergency Medicine, Kahramanmaraș, Turkey

${ }^{2}$ Kahramanmaraş Sütçü İmam University, School of Medicine, Department of Ophthalmology, Kahramanmaraş, Turkey

Corresponding author: Mete Güler, MD, Kahramanmaraş Sütçü İmam University, School of Medicine, Department of Ophthalmology, Kahramanmaraș, Turkey

E-mail: meteglr@yahoo.com

Received/Accepted: March 15, 2019 /September 28, 2019

Conflict of interest: There is not a conflict of interest.

\section{SUMMARY}

Objective: To determine the effect of intravitreal injection into different quadrants on pain score and injection comfort.

Method: 304 patients were divided into 8 groups that included 38 patients in each. The right and left eyes of the patients were divided into 4 quadrants, superior temporal, inferior temporal, superior nasal, and inferior nasal. Intravitreal injections were performed in the room only used for this purpose and by an experienced ophthalmologist. To eliminate drug-related factors only intravitreal ranibizumab applied patients were included in the study. Injections were performed on one of these quadrants $3.5 \mathrm{~mm}$ away from the limbus using 30 gauge needle. All injections were performed under topical proparacaine $\mathrm{HCl}$ anesthesia. The severity of the patient's pain after the injection was evaluated by using the visual analog scale. Additionally, the patient's stinging, injection comfort and injection safety were also assessed. Results: 176 (57.9\%) of the participants were male and 128 (42.1\%) were

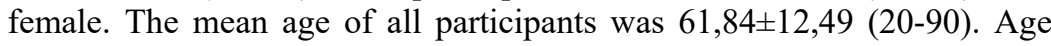
$(\mathrm{p}=0,793)$, gender $(\mathrm{p}=0,534)$, pain score $(\mathrm{p}=0,165)$, stinging score $(\mathrm{p}=0,264)$, patient comfort score $(\mathrm{p}=0,555)$, injection safety score $(\mathrm{p}=0,079)$ were similar between the groups. Pain $(p<0,001)$ and stinging $(p<0,001)$ scores were higher in females $(p<0,001)$. Patient comfort $(p=0,001)$ and injection safety $(p=0,019)$ scores were lower in females.

Conclusions: No difference was found between the quadrants in terms of pain score. Therefore, the physicians may prefer the most comfortable quadrant for themselves and for their patients in intravitreal injection.

Keywords: Pain; intravitreal injection; visual analog scale

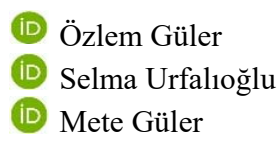

ORCID IDs of the authors: Ö.G. 0000-0002-1444-7730 S.U. 0000-0002-3709-6988 M.G. 0000-0002-6232-8445

\section{ÖZET}

Amaç: İntravitreal enjeksiyonun farklı kadranlardan yapılmasının ağrı skoruna ve enjeksiyon konforuna etkisini araştırmak.

Yöntem: 304 hasta her grupta 38 hasta olacak şekilde 8 gruba ayrıldı. Hastaların sağ ve sol gözleri üst temporal, alt temporal, üst nazal ve alt nazal olmak üzere 4 kadrana ayrıldı. İntravitreal enjeksiyonlar sadece bu amaçla kullanılan odada ve deneyimli bir oftalmolog tarafından yapıldı. İlaca bağlı etkenleri ortadan kaldırmak için sadece intravitreal ranibizumab uygulanan hastalar çalışmaya alındı. Limbustan $3.5 \mathrm{~mm}$ geriden 30 gauge iğne kullanılarak yukarıda belirtilen kadranların birinden enjeksiyon uygulandı. Tüm enjeksiyonlar topikal proparakain $\mathrm{HCl}$ anestezisi altında 
yapıldı. Enjeksiyon sonrası hastaların ağrı şiddeti görsel ağrı skalası kullanılarak değerlendirildi. Ek olarak hastaların batma, enjeksiyon konforu ve enjeksiyon emniyeti de değerlendirildi.

Bulgular: Çalışmaya katılanların 176'sı (\%57,9) erkek, 128'i (\%42,1) kadındı. Tüm katılımcıların ortalama yaşı $61,84 \pm 12,49$ (20-90) idi. Gruplar arasında yaş $(\mathrm{p}=0,793)$, cinsiyet $(\mathrm{p}=0.534)$, ağr1 skoru $(\mathrm{p}=0,165)$, batma skoru $(\mathrm{p}=0,264)$, hasta konforu skoru $(\mathrm{p}=0,555)$, enjeksiyon emniyet skoru $(\mathrm{p}=0,079)$ benzerdi. Ağr1 $(\mathrm{p}<0,001)$ ve batma $(p<0,001)$ skorları kadınlarda daha yüksekti $(p<0,001)$. Hasta konforu $(p=0,001)$ ve enjeksiyon emniyeti $(p=0,019)$ skorları kadınlarda daha düşüktü.

Sonuç: Enjeksiyon yapılan kadranlar arasında ağnı skoru açısından herhangi bir fark tespit edilememiştir. Bu nedenle hekim kendisi ve hastası için en konforlu kadranı intravitreal enjeksiyon uygulaması için tercih edebilir.

Anahtar sözcükler: Ağrı; intravitreal enjeksiyon; görsel analog skalası

\section{INTRODUCTION}

Intravitreal drug administrations have become the most common procedures in ophthalmology today, and their numbers are increasing rapidly over the years. Intravitreal injections are widely used in the treatment of age-related macular degeneration, diabetic macular edema, proliferative diabetic retinopathy, retinal vein occlusion, pathological myopia, uveitis, endophthalmitis, and many other diseases. ${ }^{1}$ Steroids, antibiotics, antiviral and antivascular endothelial growth factor (anti-VEGF) drugs can be administered intravitreally. However, in most pathological conditions, a single injection is not sufficient for the treatment of diseases. Pain during the injection affects the comfort of the injection and may even cause patients to discontinue treatment. ${ }^{2}$ In this study, we investigated the effect of intravitreal injection into different quadrants on pain scores. Thus, we aimed to determine the most painless quadrant for intravitreal injection.

\section{MATERIAL AND METHODS}

Ethics committee approval was taken for this prospective clinical study (Kahramanmaraş Sütçü İmam University Faculty of Medicine Clinical Research Ethics Committee-decision no: 2018/17/03), and the study was conducted in accordance with the Declaration of Helsinki. Patients were informed about the study content, and informed consent was obtained from the patients.

Patients with conjunctivitis, episcleritis, scleritis, uveitis, keratitis, glaucoma, ocular surface disorder, ocular surface susceptibility to any drops were excluded from the study. Patients who underwent surgical intervention other than cataracts, who could not comply with the scoring methods used in our research and who were younger than 18 years were also excluded.

A total of 304 patients participated in the study. The right and left eyes of the patients were divided into 4 quadrants as superior temporal, inferior temporal, superior nasal, and inferior nasal. Thus a total of 8 study groups each included 38 patients were formed for the right and left eyes.

Group 1: Injection into the superior temporal quadrant of the right eye group.

Group 2: Injection into the inferior temporal quadrant of the right eye group.

Group 3: Injection into the superior nasal quadrant of the right eye group.

Group 4: Injection into the inferior nasal quadrant of the right eye group.

Group 5: Injection into the superior nasal quadrant of the left eye group.

Group 6: Injection into the inferior nasal quadrant of the left eye group.

Group 7: Injection into the superior temporal quadrant of the left eye group.

Group 8: Injection into the inferior temporal quadrant of the left eye group.

Intravitreal injections were performed only in the room used for this purpose and by an experienced ophthalmologist (S.U). To eliminate drug-related factors, only patients who received intravitreal ranibizumab (Lucentis ${ }^{\circledR}$, Novartis) injections were included in the study. One drop of proparacaine $\mathrm{HCl} 0.5 \%$ (Alcaine drop, Alcon, USA) was instilled into the eye of the patient, and the periocular area was cleaned with $10 \%$ povidone. After the sterile drape was covered, the eyelid speculum was inserted to ensure the opening of the eyelids, and then to prevent intraocular contamination the eyelashes, conjunctiva, the cornea was washed with $5 \%$ povidone. After waiting for 30 seconds, the eye was again cleaned with saline. After conjunctiva was dried, the injection was performed from one of the abovementioned quadrants using a 30 gauge needle 3.5 $\mathrm{mm}$ behind the limbus. Pain sensation, stinging, injection comfort, and injection safety scores were evaluated after the injection. 
Pain, stinging, and patient injection comfort scores were determined by a doctor (Dr. Ö.G) who was a different doctor than the one who made the injection.

Pain scores were evaluated 1 minute after the injection. $^{3}$ A 10 -degree visual analog scale was used to determine the pain score $(0=$ no pain or sensation of touch, $10=$ most severe pain ever).

Stinging scores in both groups were evaluated 5 minutes after injection $(0=$ no stinging, $10=$ very sharp stinging sensation).

The comfort scores of the patients in both groups at the time of injection were evaluated with a 5degree satisfaction scale 5 minutes after injection ( $5=$ excellent, $4=$ very good, $3=$ reasonable, $2=$ poor, $1=$ very poor).

The physician who made injections (S.U) assessed the injection safety score with a 3-degree safety score $(0=$ no movement, $1=$ movement present but does not threaten the procedure, $2=$ movement that endanger the procedure).

\section{Statistical Analysis}

Statistical Package for the Social Sciences version 20 (SPSS-20) was used for statistical comparisons. Previously normality was evaluated by using the Shapiro-Wilk test. One-way analysis of variance test was used for normally distributed parameters, and Kruskal Wallis variance analysis test was used for non-normally distributed parameters. Comparison for gender was made by chi-square test. Pearson correlation analysis was performed for normally distributed parameters and Spearman correlation analysis for non-normally distributed parameters.

\section{RESULTS}

Indications for intravitreal injection were diabetes (204 patients, 67.1\%), age-related macular degeneration (62 patients, 20.3\%), retinal vein occlusion (34 patients, 11.2\%), myopic choroidal neovascular membrane (2 patients, $0.7 \%$ ) and telangiectasia ( 2 patients, $0.7 \%) .176(57.9 \%)$ of the participants were male, and $128(42.1 \%)$ were female. The mean age of all participants was $61.84 \pm 12.49(20-90)$ years. Age, pain, stinging, injection comfort, and injection safety scores of all groups are given in Table 1. Age $(\mathrm{p}=0.793)$, sex $(p=0.534)$, pain score $(p=0.165)$, stinging score $(\mathrm{p}=0.264)$, patient comfort score $(\mathrm{p}=0.555)$, injection safety score $(\mathrm{p}=0.079)$ were similar among the groups. Pain, stinging, injection comfort and injection safety scores by gender are given in Table 2. Pain $(\mathrm{p}<0.001)$ and stinging $(\mathrm{p}<0.001)$ scores were higher in women. Patient comfort scores $(\mathrm{p}=0.001)$ and injection safety scores $(p=0.019)$ were lower in women.

Table 1: Age, pain, stinging, patient comfort, and injection safety scores in groups. ( $R=$ Right, $L=L e f t$, Sup=Superior, Inf=Inferior, Nas=Nasal, Temp=Temporal, Pat=Patient, Inj: Injection)

\begin{tabular}{|l|l|l|l|l|l|}
\hline & AGE & PAIN & STINGING & PAT.COMFORT & INJ.SAFETY \\
\hline R. SUP.TEMP. & $\begin{array}{l}60,5 \pm 13,89 \\
(25-85)\end{array}$ & $\begin{array}{l}1,58 \pm 1,37 \\
(0-4)\end{array}$ & $\begin{array}{l}1,11 \pm 0,95 \\
(0-3)\end{array}$ & $\begin{array}{l}4,28 \pm 0,73 \\
(3-5)\end{array}$ & $\begin{array}{l}0,34 \pm 0,58 \\
(0-2)\end{array}$ \\
\hline R. INF. TEMP. & $\begin{array}{l}61,18 \pm 15,90 \\
(20-88)\end{array}$ & $\begin{array}{l}1,50 \pm 1,03 \\
(0-4)\end{array}$ & $\begin{array}{l}0,84 \pm 0,88 \\
(0-3)\end{array}$ & $\begin{array}{l}4,42 \pm 0,60 \\
(3-5)\end{array}$ & $\begin{array}{l}0,24 \pm 0,54 \\
(0-2)\end{array}$ \\
\hline R. SUP. NAS. & $62,29 \pm 8,55$ & $0,97 \pm 1,05$ & $0,52 \pm 0,73$ & $4,58 \pm 0,50$ & $0,16 \pm 0,44$ \\
& $(41-81)$ & $(0-3)$ & $(0-2)$ & $(4-5)$ & $0-2)$ \\
\hline R. INF. NAS. & $64,45 \pm 10,70$ & $1,55 \pm 1,08$ & $0,74 \pm 0,79$ & $4,37 \pm 0,59$ & $0,18 \pm 0,51$ \\
& $(39-89)$ & $(0-4)$ & $(0-3)$ & $(3-5)$ & $0-2)$ \\
\hline L. SUP. NAS. & $63,00 \pm 12,68$ & $1,29 \pm 0,93$ & $0,79 \pm 0,81$ & $4,47 \pm 0,73$ & $0,079 \pm 0,27$ \\
& $(20-82)$ & $(0-3)$ & $(0-3)$ & $(2-5)$ & $(0-1)$ \\
\hline L. INF. NAS. & $62,21 \pm 12,43$ & $1,37 \pm 1,07$ & $0,68 \pm 0,77$ & $4,45 \pm 0,65$ & $0,26 \pm 0,64$ \\
& $(28-90)$ & $(0-3)$ & $(0-3)$ & $(3-5)$ & $0-2)$ \\
\hline L. SUP. TEMP. & $59,55 \pm 12,93$ & $1,61 \pm 1,17$ & $0,89 \pm 1,09$ & $4,39 \pm 0,55$ & $0,26 \pm 0,16$ \\
& $(28-82)$ & $(0-4)$ & $(0-4)$ & $(3-5)$ & $(0-1)$ \\
\hline L. INF.TEMP. & $61,61 \pm 12,07$ & $1,74 \pm 1,31$ & $0,84 \pm 1,13$ & $4,29 \pm 0,69$ & $0,21 \pm 0,47$ \\
& $(20-83)$ & $(0-5)$ & $(0-4)$ & $(3-5)$ & $(0-2)$ \\
\hline
\end{tabular}


Table 2: Pain, stinging, patient comfort, and injection safety scores by sex.

\begin{tabular}{|l|l|l|l|}
\hline & MALE $(\mathrm{n}=176)$ & FEMALE $(\mathrm{n}=128)$ & P VALUE \\
\hline PAIN & $1,22 \pm 1,02(0-4)$ & $1,76 \pm 1,23(0-5)$ & $<0,001$ \\
\hline STINGING & $0,61 \pm 0,75(0-4)$ & $1,07 \pm 1,04(0-4)$ & $<0,001$ \\
\hline PATIENT COMFORT & $4,53 \pm 0,53(3-5)$ & $4,24 \pm 0,72(2-5)$ & 0,001 \\
\hline INJECTION SAFETY & $0,13 \pm 0,40(0-2)$ & $0,27 \pm 0,57(0-2)$ & 0,019 \\
\hline
\end{tabular}

When the patients in all groups were divided by age as $<65$ years ( 162 patients) and $\geq 65$ years $(142$ patients) groups, the pain $(\mathrm{p}=0.005)$ and stinging $(\mathrm{p}=0.025)$ scores were higher in the $\geq 65$ years group. Injection comfort $(\mathrm{p}=0.109)$ and injection safety $(\mathrm{p}=0.229)$ scores were similar between these two age groups. There was a positive significant correlation between age-pain $(\mathrm{r}=0.183, \mathrm{p}=0.016)$ and age-stinging $(\mathrm{r}=0.112, \mathrm{p}=0.05)$. There was a statistically insignificant negative correlation between age and patient comfort score $(r=-0,100$, $\mathrm{p}=0.082$ ). There was no relationship between age and injection safety $(\mathrm{r}=0.031, \mathrm{p}=0.588)$. There was a strong positive correlation between pain score and stinging score $(\mathrm{r}=0.656, \mathrm{p}<0.001)$. There was a statistically significant negative correlation between pain score-patient comfort $(\mathrm{r}=0.810$, $\mathrm{p}<0.001)$ and stinging score-patient comfort $(\mathrm{r}=-$ $0.656, p<0.001)$ Injection safety decreased with increasing pain $(\mathrm{r}=0.270, \mathrm{p}<0.001)$ and stinging $(\mathrm{r}=0.251, \mathrm{p}<0.001)$ scores.

\section{DISCUSSION}

Various anesthesia methods were compared in intravitreal injection. In a study comparing topical proparacaine, topical tetracaine, lidocaineimpregnated cellulose sponge and subconjunctival lidocaine anesthesia, no difference was found in terms of pain scores. ${ }^{4}$ Another study compared proparacaine drop, proparacaine drop+subconjunctival lidocaine, lidocaine gel anesthesia methods in intravitreal injection and subconjunctival lidocaine was found to be the most effective method to prevent pain and eye movements. ${ }^{5}$ Intravitreal injection after topical proparacaine anesthesia has been reported to be highly effective and inexpensive. ${ }^{3}$ We performed all intravitreal injections with topical proparacaine anesthesia.

Previous studies have found that some factors may be associated with pain in intravitreal injection. Shin et al. reported higher pain scores in women than men. ${ }^{6}$ Rifkin et al. found that pain scores were higher in men in their study. ${ }^{7}$ Masamba et al. found that pain scores between men and women were similar. ${ }^{8}$ In our study, pain and stinging scores were higher in women than men. Injection comfort and safety scores were lower in women than in men. Rifkin et al. reported that the pain score decreases in older age $(>65)$ in intravitreal injection. ${ }^{7}$ This finding is in contradiction with the results of our study. We found pain and stinging scores higher in the $\geq 65$ age group than in the $<65$ age group. The number of injections, anterior chamber paracentesis, patient anxiety, and visual gain after the first injection was found to be associated with pain in intravitreal injection. ${ }^{2,6,7} \mathrm{We}$ did not evaluate these variables in our study.

Some studies have found a relationship between pain and needle diameter during the injection. In a previous study, we found that the use of 30 gauge needles instead of 27 gauge significantly reduced pain scores in patients. ${ }^{9}$ However, another study reported that the use of a 30-gauge needle instead of a 27 -gauge needle did not have any superiority in reducing pain. Nevertheless, 30 gauge needles were preferred by all surgeons. ${ }^{10}$ We preferred 30 gauge needle for injection because we thought it was easier to exceed the scleral resistance during the injection.

There may also be a relationship between the administered drug and the severity of pain. Since the chemical structures of intravitreal medications are different, they may cause varying degrees of pain in the eye. Bilgin et al. reported that intravitreal aflibercept injection was more painful than intravitreal ranibizumab injection. ${ }^{11}$ In order to standardize the sense of drug-induced pain, only patients who received intravitreal ranibizumab injections were included in the study.

Similar to our study, Karimi et a ${ }^{12}$ divided the eyes of the patients into superotemporal, superonasal, inferotemporal, and inferonasal quadrants to evaluate the relationship between the injection site and pain severity following intravitreal injection. They used a 10-degree visual pain scale to assess pain severity. They also investigated the relationship among pain intensity during injection and the number of injections, age, sex, and indication for injection. The researchers reported that injection into the superior temporal quadrant causes the most severe pain. No significant difference was found between the quadrants in terms of pain severity in our study. These authors 
reported that the severity of pain was higher in women. This finding is consistent with our research. No relationship was reported between pain score and age in the same study. There was a significant positive correlation between age and pain and stinging scores in our study. A negative correlation was reported between pain score and number of previous injections. We did not examine this relationship in our study. Compared to this study, the number of participants was lower in our study. On the other hand the authors did not separate the eyes as right and left eyes. We formed groups with equal number of patients for each quadrant of the right and left eye in our study. We think that this detail is essential for independent evaluation of each eye.

Pain during intravitreal injection is usually mild. ${ }^{13}$ When our injections were evaluated as a whole, our pain scores were generally low. The physician who applied intravitreal injections was right-handed in this study, and injection from lower temporal quadrants was found to be more comfortable for the doctor. However, we did not measure the convenience of injection in this study. Therefore, our interpretation is a personal opinion.

\section{CONCLUSION}

Intravitreal injection with $0.5 \%$ proparacaine $\mathrm{HCl}$ is a comfortable intervention for the patient. With this form of anesthesia, patients experience a mild amount of pain. No difference was found among the quadrants in terms of pain score. Therefore, the physicians may prefer the most comfortable quadrant for themselves and for their patients in intravitreal injection.

\section{REFERENCES}

1.Grzybowski A, Told R, Sacu S, Bandello F, Moisseiev E, Loewenstein A, Schmidt-Erfurth U; Euretina Board. 2018 Update on Intravitreal Injections: Euretina Expert Consensus Recommendations. Ophthalmologica. 2018;239(4):181-93.

2.Segal O, Segal-Trivitz Y, Nemet AY, Cohen P, Geffen N, Mimouni M. Anxiety levels and perceived pain intensity during intravitreal injections.Acta Ophthalmol. 2016;94 (2):203-4.
3.Davis MJ, Pollack JS, Shott S. Comparison of topical anesthetics for intravitreal injections: a randomized clinical trial. Retina. 2012;32(4):7015.

4.Blaha GR, Tilton EP, Barouch FC, Marx JL. Randomized trial of anesthetic methods for intravitreal injections. Retina. 2011;31(5):535-9.

5.Andrade GC, Carvalho AC. Comparison of three different anesthetic approaches for intravitreal injections: a prospective randomized trial. Arq Bras Oftalmol. 2015;78(1):27-31.

6.Shin SH, Park SP, Kim YK. Factors associated with pain following intravitreal injections. Korean J Ophthalmol. 2018;32(3):196-203.

7.Rifkin L, Schaal S. Factors affecting patients' pain intensity during the in-office intravitreal injection procedure. Retina. 2012;32(4):696-700.

8.Massamba N, Elluard M, Agoune W, Guyader V, Ingram A, Pasquier B, Knoeri J. Assessment of ocular pain following ranibizumab intravitreal injection. Acta Ophthalmol. 2015;93(3):e231-2.

9.Güler M, Bilgin B, Çapkın M, Şimşek A, Bilak Ş. Assessment of patient pain experience during intravitreal 27-gauge bevacizumab and 30-gauge ranibizumab injection. Korean $\mathrm{J}$ Ophthalmol. 2015;29(3):190-4.

10.Haas P, Falkner-Radler C, Wimpissinger B, Malina M, Binder S. Needle size in the intravitreal injections-pain evaluation of a randomized clinical trial. Acta Ophthalmol. 2016;94(2):198-202.

11.Bilgin B, Bilak Ş. Assessment of patient pain Experience during intravitreal ranibizumab and aflibercept injection. Middle East Afr J Ophthalmol. 2019;26(2):55-9.

12.Karimi S, Mosavi SA, Jadidi K, Nikkhah H, Kheiri B. Which quadrant is less painful for intravitreal injection? A prospective study. Eye (Lond). Eye (Lond). 2019;33(2):304-12.

13.Shiroma HF, Takaschima AKK, Farah ME, Höfling-Lima AL, de Luca Canto G, Benedetti RH, Rodrigues EB. Patient pain during intravitreal injections under topical anesthesia: a systematic review. Int J Retina Vitreous. 2017;3:23. 